\title{
Could the employment-based targeting approach serve Egypt in moving towards a social health insurance model?
}

S. Shawky ${ }^{T}$

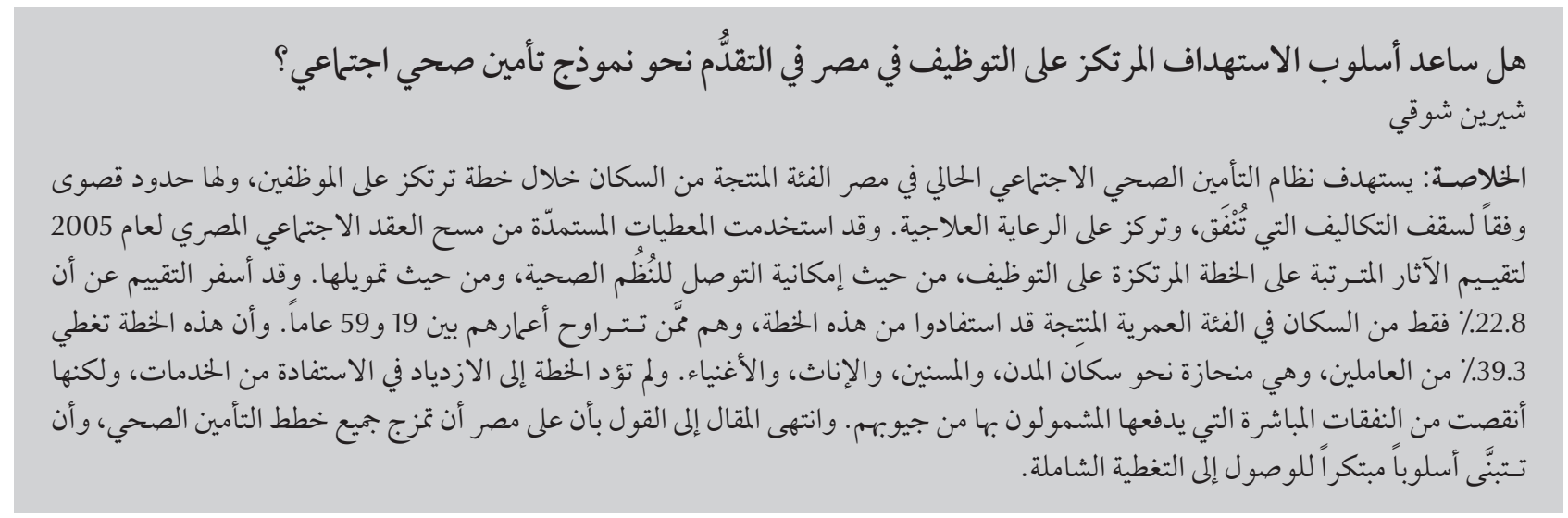

ABSTRACT The current health insurance system in Egypt targets the productive population through an employment-based scheme bounded by a cost ceiling and focusing on curative care. Egypt Social Contract Survey data from 2005 were used to evaluate the impact of the employment-based scheme on health system accessibility and financing. Only $22.8 \%$ of the population in the productive age range (19-59 years) benefited from any health insurance scheme. The employment-based scheme covered $39.3 \%$ of the working population and was skewed towards urban areas, older people, females and the wealthier. It did not increase service utilization, but reduced out-of-pocket expenditure. Egypt should blend all health insurance schemes and adopt an innovative approach to reach universal coverage.

Le ciblage fondé sur l'emploi est-il une approche pouvant aider l'Égypte à s'orienter vers un modèle d'assurance maladie sociale?

RÉSUMÉ Le système d'assurance maladie égyptien actuel cible la population active au moyen d'un dispositif fondé sur l'emploi, limité par un plafond de coûts et axé sur les soins curatifs. Les données de l'enquête sur le Contrat social égyptien réalisée en 2005 ont permis d'évaluer les effets du dispositif fondé sur l'emploi sur l'accessibilité et le financement du système d'assurance maladie. Seuls 22,8 \% de la population en âge de travailler (de 19 à 59 ans) bénéficiaient alors d'une couverture maladie. Le dispositif fondé sur l'emploi couvrait 39,3 \% de la population active et avantageait les zones urbaines, les personnes âgées, les femmes et les personnes les plus aisées. Il n'a pas contribué à augmenter l'utilisation des services, mais a diminué les paiements directs. L'Égypte devrait fusionner tous les dispositifs d'assurance maladie et adopter une approche innovante afin de parvenir à une couverture universelle. 


\section{Introduction}

Egypt is currently working on reforming its health insurance system as part of a nationwide reform of health care. In the government's sixth 5-year plan, Egypt is targeting a gradual expansion of health insurance to cover new segments of the population, until universal coverage is achieved by 2012 [1]

The development of the insurance scheme in Egypt has 2 incremental phases. The first phase started with the 1936 law to insure blue-collar workers against occupational accidents, later expanded to cover health care services rather than just occupational accidents. The second phase started with the presidential decree that announced the birth of the health insurance organization (HIO) in 1964, aiming to provide health insurance for industrial workers and civil servants. Under the control of the Ministry of Health and Population (MOHP), the HIO acts as service purchaser and provider through several rented or owned clinics and hospitals. Since then, more socio-professional groups have been brought into compulsory insurance, albeit still mainly targeted on the public sector workforce. There were 3 important landmarks to this phase: in 1981 the families of insured individuals were brought under coverage; in 1992 the school health insurance law was issued to cover all enrolled students; and in 1997 insurance coverage was expanded to children under school age.

Health insurance in Egypt is funded by government subsidy together with users' and employer contributions, as well as cigarette taxation for the school health insurance scheme. For the employment-based scheme, a fixed percentage of the salary is collected from both the employee and the employer, while for the other schemes, a fixed sum of money is charged from the beneficiary [2]. The health insurance system functions with an upper limit on the cost of the health care and focuses on curative care. In cases where the cost of medical care exceeds the threshold, limited exemptions are made with official approval from the MOHP.

The current health insurance system is being expanded towards a social health insurance model that involves compulsory membership, universal coverage and pooling of risk $[3,4]$. Evidence of the impact of the current health insurance schemes on health system performance is insufficient. The few available studies focus on the school health insurance scheme and there is scarce evidence of the impact of the employment-based health insurance targeting the population of productive age who represent Egypt's workforce and the country's main human resource.

The study aimed to evaluate the impact of the employment-based scheme on health system accessibility and financing, through 3 main questions: Does the employment-based approach reach all categories of the population? Does employment-based health insurance meet the beneficiaries' health needs? Is the employment-based health insurance scheme capable of increasing health care service utilization and relieving the financial burden borne by individuals?

\section{Methods}

\section{Study population}

The study made use of the Egypt Social Contract Survey Data from 2005 [5]. The sample was based on the same sampling frame as the Egypt Demographic and Health Survey 2005 [6]. The sample was designed to provide estimates of all major variables at the national and regional level.

Egypt is divided into 5 administrative regions covering 21 governorates (administrative geographic units). The administrative regions includse the urban governorates (Cairo, Alexandria and Suez), urban Lower Egypt, rural Lower Egypt, urban Upper Egypt and rural Upper Egypt. There were 15060 individuals in the productive age groups. Most of the records (95.3\%) had complete information on the health insurance coverage and were used for the analysis.

\section{Data and variables}

The survey data included sociodemographic information, insurance coverage details, health service utilization in the 12 months prior to data collection and total family expenditure and out-ofpocket expenditure on regular treatment and last health care service use within the 12 months prior to data collection. The analysis was restricted to the population in the productive ages: $>18$ years (upper age limit for school health insurance) and $<60$ years (lower age limit for pension health insurance). This age range was used to enable comparison between the groups with and without employment-based heath insurance and in order to demonstrate the impact of the employment-based scheme.

\section{Analysis}

The data were weighed to give estimates that were representative of the population from which the sample was drawn. In all analyses, the employmentbased health insurance was compared with other health insurance schemes among the working and non-working population, as well as with the noninsured population to represent the employment-based health insurance effect. The chi-squared test was used to detect significant difference between proportions, $t$-test was used to detect significant difference between 2 means and Kruskal-Wallis test for more than 2 means.

The impact of the health insurance coverage on increasing health care service utilization and reducing the financial burden borne by individuals was measured by 2 methods. The first method assessed the difference in the catastrophic payment head count and the out-of-pocket catastrophic payment 
excess between the employment-based scheme and the other schemes or in the absence of health insurance coverage. The "catastrophic" label refers to the fact that falling ill can induce a sizeable, unpredictable shock to an individual's living standard. The catastrophic payment head count (defined as $20 \%$ of the total expenditure [7]) is a straightforward way to measure the fraction of individuals whose health care costs exceed the threshold, thus indicating the magnitude of catastrophic payments in a population. The out-ofpocket catastrophic payment excess (calculated by subtracting 20\% from the health spending fraction for those with catastrophic payments) captures the average degree by which payments exceed the threshold, thus measuring the intensity of catastrophic payment in a population.

The second method involved a 2-part model [8-10]. Part 1 was a logit model estimating the individual's probability of using health care services. Part 2 was a log-linear model that estimated the annual per capita health expenditure incurred by an individual when using the health care services. As the employment-based scheme did not show significant interactions with the other independent variables, interaction terms were not included in the model.

STATA, version 9, computer package was used for data analysis.

\section{Results}

\section{Characteristics of the study sample}

A total of 14359 individuals in the productive age range (between 19 and 59 years) were included in the study. The working population accounted for $46.1 \%$. The majority of the non-working population $(78.5 \%)$ were females, most of them (68.3\%) housewives. The overall health insurance coverage was low, with just $22.8 \%$ of the population of productive age being covered. A higher proportion of the working population were covered by an insurance scheme (39.3\%), mostly (95.0\%) employmentbased. On the other hand, just $8.7 \%$ of the non-working population were covered. Table 1 shows the background characteristics of the study sample.

\section{Health insurance coverage}

At national level, $37.5 \%$ of the working population were covered by an employment-based scheme and only $1.8 \%$ of them had another form of health insurance coverage (Table 2). The population in urban regions benefited more than those in rural regions from health insurance. There was also a clear increasing trend in the proportion of the health insurance beneficiaries by age group among the working population for both the employment-based and the other schemes. However, the non-working population had the highest proportion covered at the 2 age extremes, especially those $\leq 29$ years, as the health insurance coverage in this age group was influenced by the school healthinsurance effect.Working females benefited more from health insurance coverage, whether employment-based or other schemes, than did working males. For the non-working population, the share of females with health insurance coverage was low compared

\begin{tabular}{|c|c|c|c|}
\hline \multicolumn{4}{|c|}{$\begin{array}{l}\text { Table } 1 \text { Background characteristics of individuals in the productive age, Social } \\
\text { Contract Survey, Egypt } 2005\end{array}$} \\
\hline Variable & $\begin{array}{c}\text { Total } \\
(n=14359)\end{array}$ & $\begin{array}{l}\text { Working } \\
\text { population } \\
(n=6626)\end{array}$ & $\begin{array}{c}\text { Non-working } \\
\text { population } \\
(n=7733)\end{array}$ \\
\hline \multicolumn{4}{|l|}{ Region $^{a}$} \\
\hline Urban governorates $^{b}$ & 28.2 & 29.1 & 27.5 \\
\hline Urban lower Egypt & 10.1 & 11.2 & 9.2 \\
\hline Rural lower Egypt & 32.9 & 32.1 & 33.6 \\
\hline Urban upper Egypt & 7.0 & 7.1 & 6.8 \\
\hline Rural upper Egypt & 21.8 & 20.4 & 22.9 \\
\hline \multicolumn{4}{|l|}{ Age (years) ${ }^{a}$} \\
\hline$\leq 29$ & 40.7 & 28.6 & 51.1 \\
\hline 30-39 & 21.6 & 25.5 & 18.2 \\
\hline $40-49$ & 20.8 & 25.8 & 16.5 \\
\hline $50-59$ & 16.9 & 20.0 & 14.1 \\
\hline \multicolumn{4}{|l|}{$\operatorname{Sex}^{a}$} \\
\hline Male & 49.9 & 83.1 & 21.5 \\
\hline Female & 50.1 & 16.9 & 78.5 \\
\hline \multicolumn{4}{|l|}{ Wealth quintiles ${ }^{a}$} \\
\hline Q1 (poorest) & 17.2 & 16.0 & 18.2 \\
\hline Q2 & 19.0 & 17.4 & 20.4 \\
\hline Q3 & 20.0 & 19.6 & 20.3 \\
\hline Q4 & 21.4 & 20.5 & 22.1 \\
\hline Q5 (richest) & 22.4 & 26.4 & 18.9 \\
\hline \multicolumn{4}{|l|}{ Health insurance scheme $e^{a}$} \\
\hline None & 77.2 & 60.7 & 91.3 \\
\hline Employment-based & 17.3 & 37.5 & 0.0 \\
\hline Private & 0.3 & 0.5 & 0.2 \\
\hline Other $^{c}$ & 5.2 & 1.3 & 8.5 \\
\hline
\end{tabular}

${ }^{a} \mathrm{p}<0.001$.

${ }^{b}$ Cairo, Alexandria and Suez.

'Through Ministry of Health and Population, syndicates, school or a family member. 


\begin{tabular}{|c|c|c|c|}
\hline \multicolumn{4}{|c|}{$\begin{array}{l}\text { Table } 2 \text { Health insurance coverage by individuals' work status and type of } \\
\text { insurance scheme, Social Contract Survey, Egypt } 2005\end{array}$} \\
\hline \multirow[t]{4}{*}{ Variable } & \multicolumn{3}{|c|}{ Health insurance coverage } \\
\hline & \multicolumn{2}{|c|}{ Working population } & \multirow{2}{*}{$\begin{array}{c}\begin{array}{c}\text { Non-working } \\
\text { population }\end{array} \\
\text { Other schemes }\end{array}$} \\
\hline & $\begin{array}{c}\text { Employment- } \\
\text { based }\end{array}$ & Other schemes & \\
\hline & $\%$ & $\%$ & $\%$ \\
\hline National $^{a}$ & 37.5 & 1.8 & 8.7 \\
\hline \multicolumn{4}{|l|}{ Region $^{a}$} \\
\hline Urban governorates & 38.7 & 3.1 & 8.8 \\
\hline Urban Lower Egypt & 56.0 & 2.0 & 16.0 \\
\hline Rural Lower Egypt & 37.4 & 1.0 & 8.7 \\
\hline Urban Upper Egypt & 46.8 & 1.9 & 8.5 \\
\hline Rural Upper Egypt & 22.7 & 0.8 & 5.6 \\
\hline \multicolumn{4}{|l|}{ Age (years) ${ }^{a}$} \\
\hline$\leq 29$ & 16.5 & 1.3 & 14.1 \\
\hline $30-39$ & 36.8 & 1.5 & 1.8 \\
\hline $40-49$ & 50.4 & 1.8 & 2.7 \\
\hline $50-59$ & 51.9 & 2.9 & 4.8 \\
\hline \multicolumn{4}{|l|}{$\operatorname{Sex}^{a}$} \\
\hline Male & 33.5 & 1.5 & 20.1 \\
\hline Female & 57.5 & 3.4 & 5.6 \\
\hline \multicolumn{4}{|l|}{ Wealth quintile ${ }^{a}$} \\
\hline Q1 (poorest) & 13.2 & 0.5 & 4.3 \\
\hline Q2 & 23.0 & 1.5 & 6.1 \\
\hline Q3 & 31.8 & 1.5 & 7.1 \\
\hline Q4 & 44.7 & 1.9 & 10.1 \\
\hline Q5 (richest) & 60.5 & 2.9 & 15.8 \\
\hline
\end{tabular}

${ }^{a} \mathrm{P}<0.001$.

with the non-working males or working females. The employment-based health insurance, as for the other insurance schemes, did not solve the problem of the lower wealth quintiles. There was a clear benefit from the health insurance coverage in favour of the wealthiest quintiles.

\section{Health insurance utilization}

At national level, it was estimated that only $41.3 \%$ of all health insurance beneficiaries used the scheme when purchasing health care. Among the working population, $43.5 \%$ of those with employment-based insurance used the scheme when purchasing health care services compared with $44.6 \%$ of beneficiaries of other scheme and $32.9 \%$ males and females or among wealth quintiles.

\section{Health service utilization and financial burden}

It was estimated that $11.6 \%$ of the individuals in the productive age group were subject to catastrophic payments, with a mean percentage of excess payment of $15.1 \%$ above the threshold (20\% of total expenditure). At national level, the insurance schemes other than the employmentbased ones appeared to be dominant in reducing the proportion of individuals subject to catastrophic payment, while the employment-based scheme was dominant in reducing the excess out-of-pocket catastrophic payment (Table 4). As for the other schemes, the employment-based insurance was able to reduce the financial burden of health care in the urban governorates and for the younger age groups.

It was estimated that $23.9 \%$ of the sample used the health services during the 12 months prior to data collection. Around $94.2 \%$ of the service users reported regular purchase of medicine for chronic illnesses, $15.1 \%$ reported needing inpatient care and $89.7 \%$ reported outpatient care. The median annual per capita out-of-pocket expenditure on medicines for chronic illnesses and a single inpatient and/or a single outpatient health care service use was 225 Egyptian pounds (LE) (US\$ 1 was equivalent to around $6 \mathrm{LE}$ at the time of data collection).

Table 5 shows the results of the 2-part model; the coefficients in the logit model were transferred into odds ratios to facilitate interpretation. The employment-based scheme did not significantly increase health service utilization; however, it significantly reduced the out-of-pocket expenditure on health care services $(P=0.031)$. The other health insurance schemes reduced the health service utilization $(P$ $=0.044$ ) but had no impact on reducing out-of-pocket expenditure on health. 


\begin{tabular}{|c|c|c|c|}
\hline $\begin{array}{l}\text { Table } 3 \text { Health insuran } \\
\text { status and type of insu }\end{array}$ & $\begin{array}{l}\text { ilization among } \\
\text { e scheme, Social }\end{array}$ & $\begin{array}{l}\text { eneficiaries by in } \\
\text { contract Survey, } E\end{array}$ & $\begin{array}{l}\text { viduals' work } \\
\text { pt } 2005\end{array}$ \\
\hline Variable & $\mathrm{He}$ & h insurance utiliz & tion \\
\hline & Working & opulation & Non-working \\
\hline & $\begin{array}{l}\text { Employment- } \\
\text { based }\end{array}$ & Other schemes & Other schemes \\
\hline & $\%$ & $\%$ & $\%$ \\
\hline National $^{a}$ & 43.5 & 44.6 & 32.9 \\
\hline Region $^{b}$ & & & \\
\hline Urban governorates & 54.7 & 44.8 & 42.9 \\
\hline Urban Lower Egypt & 45.1 & 53.3 & 34.2 \\
\hline Rural Lower Egypt & 42.6 & 52.4 & 30.8 \\
\hline Urban Upper Egypt & 29.4 & 22.2 & 28.9 \\
\hline Rural Upper Egypt & 26.6 & 22.2 & 19.2 \\
\hline Age $(\text { years })^{c}$ & & & \\
\hline$\leq 29$ & 35.4 & 36.4 & 28.7 \\
\hline $30-39$ & 35.1 & 47.8 & 20.8 \\
\hline $40-49$ & 44.2 & 40.0 & 64.7 \\
\hline 50-59 & 53.9 & 52.6 & 63.5 \\
\hline Sex & & & \\
\hline Male & 44.0 & 45.3 & 30.1 \\
\hline Female & 42.1 & 43.2 & 35.5 \\
\hline Wealth quintile & & & \\
\hline Q1 (poorest) & 37.1 & 66.7 & 29.5 \\
\hline Q2 & 44.5 & 53.3 & 34.7 \\
\hline Q3 & 40.4 & 52.6 & 29.5 \\
\hline Q4 & 45.5 & 41.7 & 31.2 \\
\hline Q5 (richest) & 44.1 & 40.0 & 35.5 \\
\hline
\end{tabular}

${ }^{a} \mathrm{P}<0.001$.

${ }^{b}$ Employment-based $\mathrm{P}<0.001$; non-working population $\mathrm{P}=0.002$.

${ }^{v}$ Employment-based $\mathrm{P}<0.001$; non-working population $\mathrm{P}<0.001$.

The model also showed that as age increased, service utilization increased significantly $(P<0.001)$, with no difference between age groups regarding out-of-pocket expenditure. Females and the lowest 3 wealth quintiles showed a significant increase in health service utilization $(P<0.001)$ compared with the other groups, and again with no significant difference in the annual outpocket expenditure on heath care.

\section{Discussion}

Implementing social health insurance in a nation is a laudable goal and it takes a considerable degree of political will the population that may be working in the informal sector or unemployed. Targeting this sector of the population is an easy way to reach a well-defined population of the workforce through their work place. Our results showed that only $22.8 \%$ of the population in the productive ages benefited from a health insurance scheme. This was nearly half the national level reported by the MOHP [14]. The difference in the proportion of health insurance coverage between the results of this study and the MOHP estimates could be explained by the influence of the school health insurance that was reported to cover $61 \%$ of children between 6 and 18 years [15].

The low health insurance coverage could be partly explained by a lack of awareness of non-obligatory health insurance schemes, as reflected in the low proportion of individuals reporting schemes other than the employmentbased and the school health insurance. It could be also due to the limited family resources in a low-income country such as Egypt. Limited resources mean that people do not think beyond their current situation even if they are aware of the benefits of an insurance scheme. These 2 factors mean that people, especially those in good health, may judge the health insurance contributions to be too expensive and choose not to insure. However, the obligatory employmentbased scheme was still unable to cover the majority of the working population as only $37.5 \%$ benefited from it.

Probably as a result of the higher likelihood of working in the formal sector, higher proportions of the working population were covered in urban areas, older age groups, among females and among the wealthier. Given the high proportion of the population who are not working in Egypt, in addition to those working in the informal sector, there is always a risk that some families, especially the disadvantaged, would have both the male and female partners falling into one of these groups. Thus the employment-based approach 


\begin{tabular}{|c|c|c|c|c|c|c|}
\hline \multirow[t]{4}{*}{ Variable } & \multicolumn{6}{|c|}{ Financial burden of health service utilization } \\
\hline & \multicolumn{2}{|c|}{ Employment-based } & \multicolumn{2}{|c|}{ Other schemes } & \multicolumn{2}{|c|}{ Non-beneficiaries } \\
\hline & $\begin{array}{c}\text { Catastrophic } \\
\text { payment }\end{array}$ & $\begin{array}{c}\text { Excess } \\
\text { payment }\end{array}$ & $\begin{array}{l}\text { Catastrophic } \\
\text { payment }\end{array}$ & $\begin{array}{c}\text { Excess } \\
\text { payment }\end{array}$ & $\begin{array}{l}\text { Catastrophic } \\
\text { payment }\end{array}$ & $\begin{array}{c}\text { Excess } \\
\text { payment }\end{array}$ \\
\hline & $\%$ & Mean \% & $\%$ & Mean \% & $\%$ & Mean \% \\
\hline National ${ }^{a}$ & 11.1 & 10.9 & 7.7 & 12.3 & 12.0 & 16.2 \\
\hline \multicolumn{7}{|l|}{ Region $^{b}$} \\
\hline Urban governorates & 6.7 & 5.2 & 9.3 & 12.3 & 9.3 & 7.5 \\
\hline Urban Lower Egypt & 10.8 & 7.3 & 8.1 & 5.4 & 15.8 & 18.5 \\
\hline Rural Lower Egypt & 14.5 & 16.1 & 5.6 & 20.1 & 13.1 & 18.1 \\
\hline Urban Upper Egypt & 13.2 & 12.4 & 11.1 & 4.8 & 13.6 & 19.1 \\
\hline Rural Upper Egypt & 11.8 & 15.4 & 7.3 & 6.2 & 12.0 & 22.1 \\
\hline \multicolumn{7}{|l|}{ Age $(\text { years })^{c}$} \\
\hline$\leq 29$ & 5.8 & 6.9 & 3.6 & 4.6 & 5.3 & 8.7 \\
\hline $30-39$ & 6.7 & 7.8 & 11.5 & 18.1 & 11.0 & 17.0 \\
\hline $40-49$ & 11.8 & 12.9 & 14.1 & 35.0 & 18.4 & 19.8 \\
\hline 50-59 & 16.4 & 13.1 & 26.7 & 42.3 & 25.9 & 33.3 \\
\hline \multicolumn{7}{|l|}{ Sex } \\
\hline Male & 10.6 & 11.0 & 6.1 & 16.1 & 9.7 & 16.4 \\
\hline Female & 12.6 & 10.7 & 9.3 & 8.2 & 13.9 & 16.0 \\
\hline \multicolumn{7}{|l|}{ Wealth quintiles } \\
\hline Q1 (poorest) & 17.4 & 42.2 & 7.7 & 29.0 & 13.1 & 16.8 \\
\hline Q2 & 10.9 & 21.4 & 9.8 & 20.9 & 12.0 & 23.7 \\
\hline Q3 & 12.5 & 8.4 & 10.8 & 19.6 & 12.5 & 16.1 \\
\hline Q4 & 10.6 & 8.5 & 7.7 & 9.0 & 11.7 & 13.1 \\
\hline Q5 (richest) & 10.0 & 7.0 & 5.4 & 3.8 & 10.6 & 10.0 \\
\hline
\end{tabular}

${ }^{a}$ Catastrophic payment $\mathrm{P}<0.001$; excess payment $\mathrm{P}<0.001$.

${ }^{b}$ Employment-based, catastrophic and excess payment $\mathrm{P}<0.001$; non-beneficiaries, catastrophic and excess payment $\mathrm{P}<0.001$.

'Employment-based, catastrophic and excess payment $\mathrm{P}<0.001$; other schemes, catastrophic and excess payment $\mathrm{P}<0.001 ;$ non-beneficiaries, catastrophic and excess payment $\mathrm{P}<0.001$.

\begin{tabular}{|c|c|c|c|c|c|}
\hline \multirow[t]{2}{*}{ Variable } & \multicolumn{3}{|c|}{$\begin{array}{l}\text { Probability of health } \\
\text { service utilization }\end{array}$} & \multicolumn{2}{|c|}{$\begin{array}{c}\text { Conditional expenditure: } \\
\text { log-linear model }\end{array}$} \\
\hline & OR & $95 \% \mathrm{Cl}$ & $P$-value & Coefficient & $P$-value \\
\hline Employment-based insurance & 1.02 & 0.95-1.10 & 0.508 & -2.16 & 0.031 \\
\hline Other insurance scheme & 0.89 & $0.79-1.00$ & 0.044 & 0.68 & 0.498 \\
\hline Rural area & 1.04 & $0.99-1.10$ & 0.133 & 0.32 & 0.751 \\
\hline Age $\leq 29$ years & 0.39 & $0.37-0.42$ & $<0.001$ & -0.24 & 0.812 \\
\hline Age $30-39$ years & 0.54 & $0.50-0.58$ & $<0.001$ & -0.30 & 0.764 \\
\hline Age $40-49$ years & 0.77 & $0.72-0.82$ & $<0.001$ & -0.27 & 0.784 \\
\hline Female & 1.20 & $1.14-1.26$ & $<0.001$ & -0.44 & 0.657 \\
\hline Wealth quintile 1 (poorest) & 1.21 & $1.11-1.31$ & $<0.001$ & -0.87 & 0.382 \\
\hline Wealth quintile 2 & 1.20 & $1.10-1.30$ & $<0.001$ & -0.59 & 0.556 \\
\hline Wealth quintile 3 & 1.18 & $1.09-1.27$ & $<0.001$ & -0.65 & 0.513 \\
\hline Wealth quintile 4 & 1.05 & $0.97-1.14$ & 0.210 & -0.33 & 0.745 \\
\hline
\end{tabular}

$O R=$ odds ratio $; C I=$ confidence interval. 
will always be problematic in reaching these categories of the population and their families, with resulting disparities in health insurance coverage. Consequently, it is expected that even with the expansion of the employment-based approach, coverage will be always skewed towards the most favoured population, in addition to the fact that universal coverage will be difficult to achieve.

The results of this study have shown that health insurance coverage did not meet the health needs of all beneficiaries. Given that the health insurance coverage was $22.8 \%$ and just $41.3 \%$ of the beneficiaries utilized the schemes in purchasing health care, this means that the schemes met the health needs of just $9.4 \%$ of the productive population. The employment-based scheme was more prevalent, covering $37.5 \%$ of the working population, but just $43.5 \%$ of those insured used the scheme in purchasing health care, thus the actual benefit from this scheme was estimated to be $16.3 \%$ of the working population. The urban skew in the employment-based scheme coverage was reflected in its utilization.

The fact that the system was not responsive to the health needs of all beneficiaries may be also influenced by the cost ceiling that may be too low to cope with the cost of the advancements in medical practice and the new technologies used to cure illnesses. Previous experience has also shown that health insurance systems in some countries suffer from non-compliance of health care providers, who prefer to charge the medical care costs directly in order to secure their payments [16].

The skew towards older ages in the employment-based scheme was also reflected in utilization, as the scheme was overburdened by insured users who were older and would be expected to be medium to high health risk. This adverse selection overloads the cost of health care and may risk sacrificing quality of care or mislead policy-makers into reducing the cost ceiling limit or charging individuals with more contributions.
This study aimed to assess the utilization of health services and the financial burden borne by individuals using the health services. However, the inpatient and outpatient utilization and cost may have been underestimated as they refer to theoptimal condition of being subject to just one inpatient and/or outpatient event per year. Thus, the results should be interpreted with caution as they do not refer to actual annual health service utilization or per capita out-of-pocket expenditure on health. Although the employment-based scheme was not able to reduce the proportion of people subject to catastrophic payment, which is a reflection of the limited services provided or the unsuitability of the cost ceiling level, it is worth mentioning that the scheme contributed to reducing the excess out-of-pocket catastrophic payment. The employment-based scheme also failed to reduce the magnitude and intensity of catastrophic payment in rural areas and for the older population.

The results of the 2-part model showed that the current employmentbased scheme was not effective in increasing health service utilization, but succeeded in reducing out-of-pocket expenditure on health. Health service utilization is a mix of multiple factors that depend on the availability of services, the quality of services and the extra out-of-pocket expenditure on health. Consequently, if services are not available or if their quality does not meet the beneficiaries' expectations, utilization is not expected to increase even in the presence of insurance coverage. Moreover, if the cost ceiling for the scheme is low and does not cover most of the health care expenses, the burden of out-of pocket expenditure on health borne by beneficiaries will not encourage them to use the services.

This is another concern that calls for examination of the health services provided and the cost ceiling. The model has also confirmed that the health service utilization was overburdened by females, the lowest 3 wealth quintiles and those aged at least 50 years, the categories expected to be medium to high health risk who benefited from an equal annual out-of-pocket expenditure on health similar to those postulated to be have low health risk.

If social health insurance remains a key health policy goal, Egypt is invited to take well-planned steps towards a workable social health insurance structure. As experience has shown, planning and implementation are expected to take time and the system is anticipated to progress with speed corresponding to the current percentage coverage and the economy of the country until universal coverage is achieved [17]. It is recommended that Egypt works on blending all types of health insurance schemes into a family model in an attempt to progress towards a social health insurance structure. The situation calls for adopting an innovative approach to progress towards universal coverage. There is a need to combine multiple identification sources in an attempt to identify any of the family members and tracking the identified member to cover the whole family in a process such as the network chain referral. This multiple channel approach may reduce the risk of overburdening the system with high health risks and may progress towards the principle of risk sharing.

The most difficult part of developing health insurance is recalculating the cost ceiling to meet the health needs of the country. This needs very cautious assessments of family income, population health needs and the actual cost of health care, taking into consideration family size and structure [17]. Debate may arise that the current contributions are too little to support the system; yet multiple efforts may assist through various fronts. First, risk sharing in the early stages of expansion may help in balancing the expenditure, as the rich will support the poor and the healthy will support the unhealthy. Secondly, widening the focus of the health insurance to include preventive care will reduce 
the incidence of diseases and reduce the cost of curative care. A third helping factor would be to redefine the role of the $\mathrm{HIO}$ to be similar to its peers worldwide as a purchaser of health services and not a competitor to health service providers. As a purchaser of health services the $\mathrm{HIO}$ would relieve itself from the burden of health service provision and could demand that the MOHP ensures the provision of quality health care. The MOHP would charge the HIO with the actual health care fees, which would liberate the MOHP from the obligation of offering free health care and losing revenue. Consequently, government subsides could be mobilized gradually from MOHP expenditure to supporting health insurance funding.

Most of all, Egypt needs to develop a culture of health insurance within the country, through health insurance awareness programmes targeting all categories of the population.

\section{Acknowledgements}

The author would like to thank the IUSSP Scientific Panel on Health
Equity and Policy in the Arab World and the Social Research Center of the American University in Cairo for giving her the opportunity to share the draft results with the researchers from the region during the seminar on "Health inequity: current knowledge and new measurement approaches" held in Cairo on 16-18 February 2008, and received financial support from the Wellcome Trust, the Dutch Ministry of Foreign Affairs and the World Health Organization Regional Office for the Eastern Mediterranean.

\section{References}

1. Egypt's health sector reform and financing review. February 2004. New York. World Bank, 2004 (Document No. 41197).

2. Nandakumar A et al. Health reform for children: the Egyptian experience with school health insurance. Health policy, 2000, 50:155-70.

3. Carrin G, James C. Reaching universal coverage via social health insurance: key design features in the transition period. Discussion paper no. 2. Geneva, World Health Organization, 2004 (EIP/ FER/DP.04.2).

4. Carrin G, James C. Social health insurance: key factors affecting the transition towards universal coverage. International social security review, 2005, 58(1):45-64.

5. Ramadan M. Social contract database booklet. Cairo, Egyptian Cabinet, Information and Decision Support Center, 2005.

6. El Zanaty F, Way A. Egypt Demographic and Health Survey 2005 Cairo, Ministry of Health and Population, National Population Council, El-Zanaty and Associates and ORC Macro, 2005.

7. Catastrophic health care payments. Technical note no. 18. New York, World Bank Group, 2006.

8. Duan N. Smearing estimate: a nonparametric retransformation model. Journal of the American Statistical Association, 1983, 78:605-10.

9. Mann WG et al. Health insurance and demand for medical care: evidence from a randomized experiment. American economic review, 1987, 77(3):251-77.
10. Manning WG, Duan N, Rogers WH. Monte Carlo evidence on the choice between sample selection and two-part models. Journal of econometrics, 1987, 35:59-82.

11. Bäringhausen T, Sauerborn R. One hundred and eighteen years of the German health insurance system: are there any lessons for middle and low-income countries? Social science and medicine, 2002, 54(10):1559-87.

12. Hofmarcher M, Rack H. Health care systems in transition: Austria. Copenhagen, World Health Organization, European Observatory on Health Systems and Policy, 2001.

13. Ogawa $S$ et al. Scaling up community health insurance: Japan's experience with the 19th century Jyorei scheme. Health policy and planning, 2003, 18(3):270-8.

14. Rateb S. Health insurance statistics. Cairo, Egyptian Cabinet, Information and Decision Support Center, 2007.

15. Yip W, Berman P. Targeted health insurance in a low income country and its impact on access and equity in access: Egypt's school health insurance. Health economics, 2001, 10:207-20.

16. Carrin G. Social health insurance in developing countries: A continuing challenge. International social security review, 2002, 55(2):57-69.

17. Saltman R, Busse R, Figueras J. Social health insurance systems in Western Europe. European Observatory on Health Systems and Policies Series. Maidenhead, England, Open University Press, 2004. 